It has been suggested that the modern tendency in tuberculosis is to treat $x$-ray films. But, as Medlar ${ }^{13}$ has said, "the final outcome depends more upon the underlying pathological condition than it does upon the presence or absence of signs and symptoms. For the clinician, the nearest approach to the pathological status of tuberculosis is the leucocyte reaction."

References

1 Sabin, F. R.: Tubercle, 1932, xiii, 206.

2 Doan, C. A., and Sabin, F. R.: Journ. Exper. Med., 1930 (Supp'ement No. 3), 113.

s Medlar, E. M., and P'esquera, G. S.: Amer. Rev. of Tuberculosis, 1931, xxiii, 267.

- Briskman, A. L.: Ibid., 1930, xxii, 562.

- Cummins, S. Lyle: Tubercle, 1931, xii, 155

Bonsdorff, A. von: Beitr. z. klin. d. Tub., 1912-13, Suppt. 3-5, 1913, Suppt., Bd. v.

- Birkhaug, K. E.: Ann. de l'Inst. Pasteur, 1932, xlix, 630.

- Fahraeus: Biochem. Zeit., 1918, lxxxix, 355.

- Katz: Zeit. f. Tuberk., 1922, xxxv, 401

10 Westergren: Acta Med. Scand., 1921, liv, 247

1 Trail, R. R.: Lancet, 1933, i, 522.

12 Trail, R. R. : Lancet, 1933, i, 522.

${ }_{12}^{12}$ Heaf, F. R. G., Tubercle, 1926, viii, 97.

${ }^{14}$ Houghton, I. E.: Tubercle, 1932, xiii, 385 .

15 Medlar, E. M.: Amer. Rev. of Tuberculosis, 1931, xxiii, 267.

16 Shaw, A. F. B.: Journ. Path. and Bact., 1930, xxx.

17 Simpson, R. H.: Brit. Journ. Radiol., 1933, vi, 705.

\section{INHALATION THERAPY}

BY

\section{F. LOCKETT, M.B., B.S.LOND. HOUSE-PHYSICIAN, ROYAL, FREE HOSPITAL}

Inhalation therapy has been but little used in England. It is claimed that the tracheo-bronchial mucous membrane has great absorptive power and that drugs given by this method are rapidly absorbed into the blood stream. The experimental work has mainly been carried out in Gérmany ; dogs, cats, and rabbits have been used: atomized liquids have been supplied to these animals, and the size of the droplet required for inhalation therapy has been determined on the basis of animal experiments.

Wolfgang Heubner, ${ }^{1}$ in a paper on the inhalation of atomized liquids, dated 1919, gives an interesting account of this work. The earlier experiments consisted of injections of various solutions and suspensions into the trachea of an animal which was killed a few minutes later, the lungs immediately being fixed and examined. $H$. Nothnagel $^{2}$ allowed rabbits to aspirate their own blood; three and a half minutes later the animal was killed and the lungs were examined immediately. Red blood cells were found in the interstitial tissue of the lungs, in the lumen of the smaller bronchi with their long axes at right angles to the bronchial walls, and in the act of penetrating between the cells of the bronchial epithelium.

W. Fleiner ${ }^{3}$ found that the absorption of particles of Indian ink after tracheal injection was extremely rapid. $\mathrm{He}$ claims that carbon particles may reach the lymph nodes in twelve seconds. Sehrwald ${ }^{4}$ injected a solution of dye into the trachea of a rabbit and half a minute later caused the animal to inhale lycopodium; immediately afterwards the rabbit was killed and the lungs were examined. In the lumen of many small stained bronchi were unstained lycopodium granules. The dye solution must therefore have been very rapidly absorbed.

A further demonstration of the rapid absorption of solutions in oil or water is afforded by the experiments of Heubner. $\mathrm{He}$ injected a concentrated solution of malachite green into the lower part of the trachea of a cat and killed the animal by dividing both carotid arteries, while perfusing the vascular system through the jugulars to wash away as much blood as possible. The respiration stopped in two minutes and the heart in four minutes. On dissection the muscles were found to be stained green, especially on the breast. The heart and liver were deeply stained ; the intestines, kidney, bladder, urethra, and intima of large arteries were lightly stained. The spleen, peritoneum, pericardium, and urine were unstained. In the lungs the smaller bronchi were deeply stained; dye had reached many alveoli and had perfused outward. The pleura was unstained. He calculated that the maximum time for absorption had been sixteen minutès.

A similar test, using an atomized liquid, was carried out. A twenty-minute inhalation of 20 per cent. potassium ferrocyanide was given through a Spiess-Dräger atomizer. After twenty minutes ferrocyanide was present in the urine. The mucous membrane of the trachea was deeply stained for a few centimetres below the cannula, that of the main bronchi very lightly stained, and that of smaller bronchi not at all. At the bifurcations of the branches heaped-up stain was found. $\mathrm{He}$ concludes that the absence of staining in the smaller bronchi resulted from the very rapid absorption of ferrocyanide.

Kaestle, ${ }^{5}$ using rabbits under chloroform anaesthesia, was able to stain the whole bronchial tree and the alveoli with ferrocyanide. Narcosis may have hindered absorption, and a different type of animal was used.

I. Sikorsky ${ }^{6}$ caused dogs and rabbits to die from asphyxia as a result of the aspiration of sodium indigo sulphate; the trachea was immediately filled with absolute alcohol to precipitate the dye. Granules of dye were found between the cells of the bronchial epithelium, and streaks of dye were found in the peribronchial tissues. The cells of the bronchial epithelium were unstained. Sinkosky produced similar evidence. Heubner, using Victoria blue dye in olive oil, showed that oil drops passed between the cells of the bronchial epithelium, and that dye was absorbed from the oil drops by the bronchial epithelial cells. The dye was introduced into the trachea; eight minutes later the animal was killed. The lungs were kept in formalin for three days and examined in frozen section.

These experiments show conclusively that very rapid absorption occurs from the tracheo-bronchial mucous membrane, both for aqueous solutions and for those in which oil is used as a solvent. The depth to which atomized liquids penetrate the bronchial tree is very diffcult to determine because of this rapid absorption. Most of the experiments have been carried out with an intratracheal cannula, but Hofbauer ${ }^{7}$ allowed dogs to inhale through the nose and the findings were similar. Dye is found at the points of division of the bronchi, down to minute branches, and in some cases in the alveoli. In Heubner's tests the dyes used were malachite green and Victoria blue oil ; the Spiess-Dräger apparatus and the Tancre apparatus were employed. The former apparatus produced the more dense vapour with larger drops and with it only were drops of dye found in the alveoli.

\section{Clinical Investigation}

Dr. L. S. T. Burrell was using a Collinson's inhaler in the wards of the Royal Free Hospital, and when I was his house-physician he asked me to carry out some experiments to show the degree and rate with which certain drugs were absorbed and also to give an analysis of the results of cases treated in the hospital. The effects of inhalation of pure oxygen were studied both on patients and on students. A gauge was used to determine the rate of flow of oxygen from a cylinder, and the dial controlling the supply of oxygen was set at different levels according to the amount of oxygen in the cylinder. If the oxygen were delivered at more than ten litres a minute there 
TABLE I.-Comparing the Effect on the Blood Pressure of an Inhalation of Pure Oxygen through the Atomizer, and the same after $a 1$ in 1,000 Adrenaline Solution had been put into the Atomizing Flask

(The inhalations were given to patients who had been resting in bed for many hours; the patients were not disturbed for the inhalation, and all had had previous practice inhalations.)

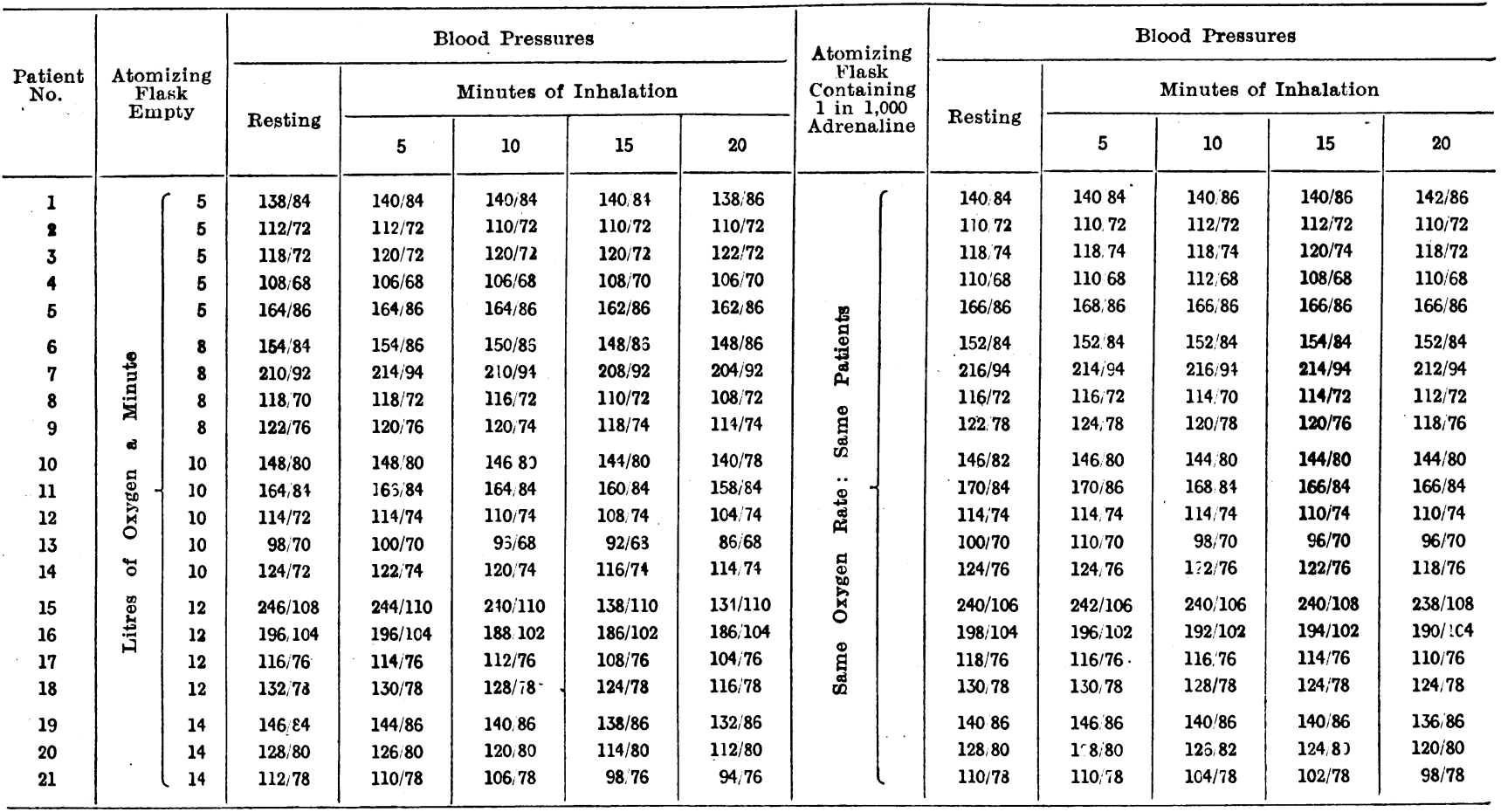

was a steady fall of systolic blood pressure ; the diastolic pressure often showed a slight initial rise, but was usually not much altered. The pulse pressure was decreased in many cases. As the flow of oxygen was increased the fall in systolic blood pressure was often increased ; symptoms of giddiness were not uncommon with oxygen rates of twelve and fourteen litres a minute.

If the oxygen were passed through an atomizer as before, but a 1 in 1,000 adrenaline solution was put into the flask, the fall in blood pressure with oxygen rates of eight, ten, and twelve litres a minute was reduced ; there was no

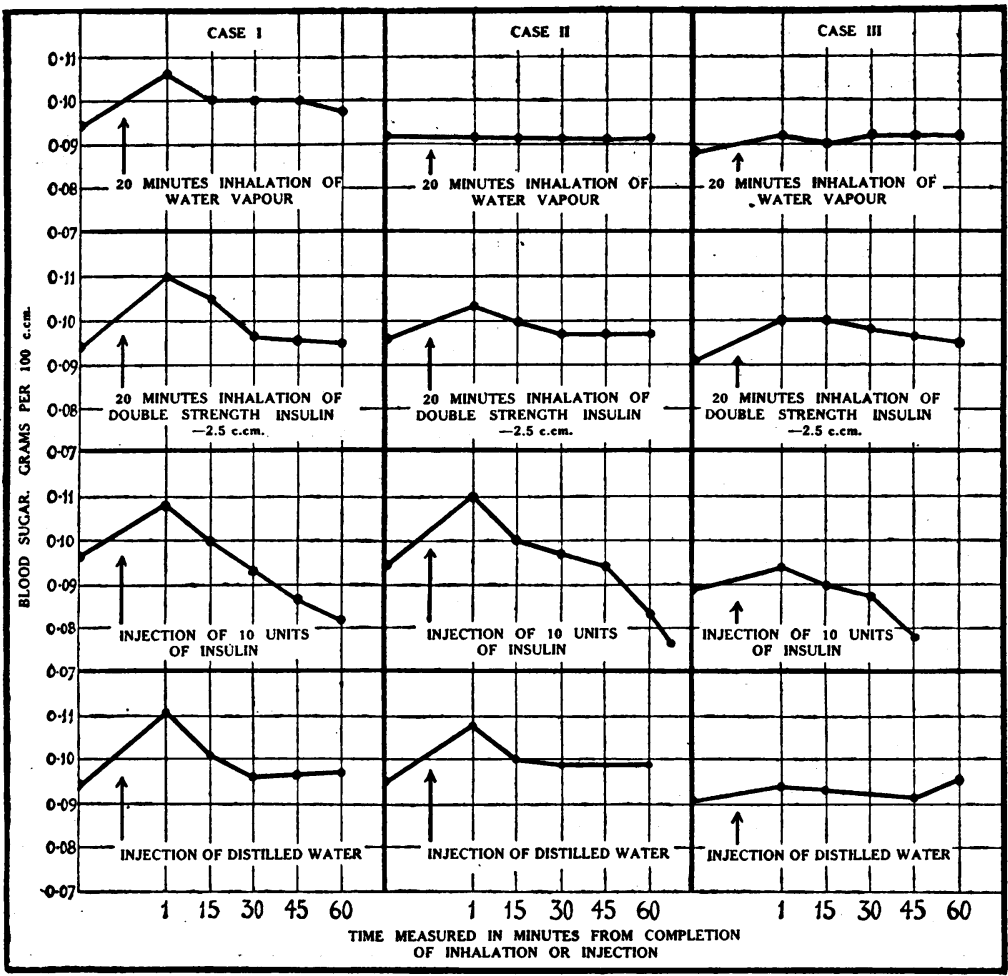

Showing the effect of injections and inhalations of water and insulin on the blood sugar. The curve in each case starts from the resting bloodsugar level.
112 to $104 \mathrm{~mm}$. of $\mathrm{Hg}$. A second student inhaled iodides for fortyfive minutes with an average oxygen rate of 10.5 litres a minute. No trace of iodide was found in the urine at the end of the inhalation; blood pressure readings have been lost. Rough attempts to find iodides in the blood with starch solution and hydrochloric acid failed. A third student inhaled iodides for twentythree minutes with an average oxygen rate of 14 litres a minute. The inhalation was stopped, since the student complained of giddiness. The systolic blood pressure had fallen from 116 to 98 . About 0.25 c.cm. of solution had been used. No trace of iodide was found in change noted in the blood pressure findings at lower pressures from those in which pure oxygen had been used.

The adrenaline was replaced by 40 per cent. potassiurn iodide solution. A student inhaled the atomized potassium iodide for ninety-five minutes with an average oxygen rate of 4.5 litres a minute (varied six to four litres one minute). Iodides were not found in the urine. No symptoms followed. The systolic blood pressure fell from urine; there was slight nasal catarrh the following day.

These experiments were repeated, both on students and on patients. Two patients were found to have traces of iodide in the urine; it was later discovered that they had been taking iodides medicinally before admission to hospital, in both cases within two weeks of the test.

Having failed with iodides to produce evidence of their absorption inhalations of insulin were used. Tests were 
made at 7 a.m. with a fasting blood sugar and at 5 p.m., no food being taken after 12 noon. Each student was given an inhalation of water vapour and one of insulin; each inhalation lasted twenty minutes, and the rate of the oxygen flow was 10 litres a minute. It was found that approximately $2.5 \mathrm{c} . \mathrm{m}$. of concentrated insulin (10 units) had disappeared from the flask during each inhalation; each student was therefore given 10 units of insulin by injection and an injection of a similar volume of water. Readings were taken by estimating the blood sugar immediately before and immediately after the inhalation or injection and every quarter of an hour for one hour afterwards. It was found that ten units of insulin by injection lowered the b'ood sugar within the hour. Inhalation of insulin usually produced a curve similar to the curve after inhalation of water vapour: in two cases the blood sugar remained slightly raised. Students were not informed whether insulin or water was being used.

If drugs are to be given by inhalation to, produce general effect an inhalation of over twenty minutes' duration is not practicable. With a flow of oxygen of 10 litres a minute about $2.5 \mathrm{c.cm}$. of liquid are removed from the flask. If a therapeutic dose of a drug is to be given it must, in many cases, be in very concentrated form. Under the condition of the experiments described it was not possible to show that the drugs were absorbed. It appears that the size of droplet judged suitable for penetration deep into the bronchial tree has been calculated on the basis of animal experiments. Aqueous solu-

TABLE II.-Twenty Patients Treated by Inhalations

\begin{tabular}{|c|c|c|c|c|c|}
\hline Series No. & A: & Sex & Disease & Treatment & Result \\
\hline 1 & 29 & F. & $\begin{array}{l}\text { Asthma and bronchitis; some emphysema. } \\
\text { Winter bronchitis since childhood. } \\
\text { A sthma for } 3 \frac{1}{2} \text { years, associated with } \\
\text { a tacks of bronchitis and increasing in } \\
\text { severity }\end{array}$ & $\begin{array}{l}\text { Apnengene and camphengene in- } \\
\text { halations } 5 \text { min. each. Increased } \\
\text { to } 10 \text { min. each for } 2 \text { weeks. Creo- } \\
\text { sote and camphengene } 1 \text { week }\end{array}$ & $\begin{array}{l}\text { Some relief during attacks of asthma from } \\
\text { apnergene. Camphengene stimulated } \\
\text { deep breathing and was useful as form } \\
\text { of breathing exercise. Cure did not } \\
\text { result and recourse was had to iodides, } \\
\text { etc. Final result great improvement }\end{array}$ \\
\hline 2 & 19 & F. & $\begin{array}{l}\text { Status asthmaticus. Severe bronchitis } \\
3 \text { years before. A sthma since, often } \\
\text { very severe. Not necessari.y associated } \\
\text { with bronchitis }\end{array}$ & $\begin{array}{l}\text { Apnengene and camphengene- } \\
30 \text { min. inhalation of apnengene; } \\
5 \text { min. inhalation camphergene }\end{array}$ & $\begin{array}{l}\text { Apnengene at first relieved attacks, later } \\
\text { failed completely. } \\
\text { slight relief, some increase in respiratory } \\
\text { exercise; pulse volume increased }\end{array}$ \\
\hline 3 & 46 & M. & $\begin{array}{l}\text { Asthma and chronic bronchitis. Recur- } \\
\text { reut bronchitis sirce winter 1934-5. } \\
\text { First attack of asthma spring, 1935, } \\
\text { increasing in severity and frequency }\end{array}$ & $\begin{array}{l}\text { Apnengene and camphengene } \\
2 \text { weeks, followed by iodides ald } \\
\text { colon irrigation }\end{array}$ & $\begin{array}{l}\text { Relief of asthma: no change in bronchitis• } \\
\text { Final condition much improved }\end{array}$ \\
\hline 4 & 18 & F. & Asthma & $\begin{array}{l}\text { Apnengene and camphengene } \\
3 \text { weeks }\end{array}$ & $\begin{array}{l}\text { No asthma while in hospital. Recurred } \\
\text { after disoharge }\end{array}$ \\
\hline 5 & 61 & M. & $\begin{array}{l}\text { Asthma and pulmonary fibrocis. Worked } \\
\text { in sawdust for } 50 \text { years. First attack of } \\
\text { asthma followed pneumonia at age of } 35\end{array}$ & $\begin{array}{l}\text { Apnengene and camphengene } \\
2 \text { weeks; upnengene and creosote } \\
\text { 1 week }\end{array}$ & $\begin{array}{l}\text { No improvement. Other methods of } \\
\text { treatment were used after } 2 \text { weeks }\end{array}$ \\
\hline 6 & 46 & F. & $\begin{array}{l}\text { Asthmia for } 32 \text { years ; bronchitis every } \\
\text { winter for } 20 \text { years. } \\
\text { out the last summer }\end{array}$ & $\begin{array}{l}\text { Apnengens and camphengen e, } \\
\text { apnengene and pine oil, apnengene } \\
\text { and creosote, cumphengene }\end{array}$ & $\begin{array}{l}\text { Very deflnite clinical improvement. No } \\
\text { change in } x \text {-ray appearances. Recurred } \\
\text { after discharge; no permanent improve- } \\
\text { ment }\end{array}$ \\
\hline 7 & 69 & м. & $\begin{array}{l}\text { Asthma and bronchitis each winter for } \\
5 \text { years }\end{array}$ & $\begin{array}{l}\text { Apnengene and cam phengene } \\
2 \text { weeks. } \\
\text { Other forms of treatment were then } \\
\text { used with inhalation therapy as above }\end{array}$ & $\begin{array}{l}\text { No change. } \\
\text { Improved. } \\
\text { Final } x \text {-ray, no change }\end{array}$ \\
\hline 8 & 34 & F. & $\begin{array}{l}\text { Chronic bronchitis and emphysema. In- } \\
\text { sidious onset during last } 7 \text { years }\end{array}$ & Inhalations as in No. 6 & $\begin{array}{l}\text { Improved. Improvement } \\
\text { throtghout the summer. } \\
\text { cleared }\end{array}$ \\
\hline 9 & 58 & F. & $\begin{array}{l}\text { Chronic bronchitis and emphrsema. } \\
\text { Cough since pneumonis } 9 \text { years pre- } \\
\text { viously }\end{array}$ & $\begin{array}{l}\text { Apnengene and camphengene } \\
2 \text { weeks; iodides, gr. } 10 \text { added. } \\
\text { Inhalations continued }\end{array}$ & $\begin{array}{l}\text { No change } \\
\text { Improved }\end{array}$ \\
\hline 10 & 60 & F. & $\begin{array}{l}\text { Pulmonary fibrosis, and congestive heart } \\
\text { failure (chronic) }\end{array}$ & Camphengene 5 min. b.d. & $\begin{array}{l}\text { Pulse improved; respirations deepened; } \\
\text { cyanosis decreased. Cough followed } \\
\text { with free expectoration. Cyanosis } \\
\text { returned in 5-20 minutes }\end{array}$ \\
\hline 11 & 52 & M. & $\begin{array}{l}\text { Bronchitis and acute congestive failure. } \\
\text { Auricular fibrillation. On recovery from } \\
\text { the acute congestive failure crepitation } \\
\text { remained, with poor air entry at both } \\
\text { bases; lung condition remained station- } \\
\text { ary for } 2 \text { weeks }\end{array}$ & Camphengene 10 min. b.d. & $\begin{array}{l}\text { Lung bases clear of crepitations after } \\
3 \text { days }\end{array}$ \\
\hline 12 & 68 & M. & $\begin{array}{l}\text { Recovering from congestive heart failure. } \\
\text { Crepitations at right base persistent and } \\
\text { unchanged for } 3 \text { weeks }\end{array}$ & Camphengene $10 \mathrm{~min}$. b.d. & $\begin{array}{l}\text { Right lung lase clear of crepitations in } \\
5 \text { das } s\end{array}$ \\
\hline 13 & 61 & M. & $\begin{array}{l}\text { Cardiovascular degeneration. Bronchi- } \\
\text { ectasis }\end{array}$ & Camphengene $10 \mathrm{~min}$. b.d. & $\begin{array}{l}\text { Appeared to make expectoration less } \\
\text { difficult }\end{array}$ \\
\hline 14 & 76 & F. & $\begin{array}{l}\text { Myocardial degeneration; congestion of } \\
\text { lung bases; cyanosis }+\end{array}$ & Camphengene $10 \mathrm{~min}$. b.d. & $\begin{array}{l}\text { Air entry and expansion at lung bases } \\
\text { increased. Cyanosis decreased }\end{array}$ \\
\hline 15 & 48 & F. & $\begin{array}{l}\text { Purmonary fibrosis : chronic bronchitis: } \\
\text { ccugh and purulent sputum for } 4 \text { years. } \\
\text { No evidence of bronchiectasis (lipiodol). } \\
\text { Haemoptysis } 5 \text { weeks previously }\end{array}$ & As No. 6. After 2 weeks iodides gr. 10 & $\begin{array}{l}\text { No improvement in first two weeks. Much } \\
\text { iml roved at time of discharge; sputum } \\
\text { decreased in amount. Improvement } \\
\text { maintained throughout the summer }\end{array}$ \\
\hline 16 & 36 & F. & $\begin{array}{l}\text { Chronic bronchitis } 10 \text { years. Tubular } \\
\text { bronchiectasis left base behind heart }\end{array}$ & $\begin{array}{l}\text { Camphengene } 5 \text { min., creosote } \\
10 \text { min., b.d. }\end{array}$ & $\begin{array}{l}\text { Appeared to aid free expectoration if } \\
\text { given before postural drainage }\end{array}$ \\
\hline 17 & 52 & F. & $\begin{array}{l}\text { Bronchitis all year round since childhood. } \\
\text { Bronchiectasis at right base }\end{array}$ & $\begin{array}{l}\text { Camphengene and creosote as in } \\
\text { No. } 16\end{array}$ & $\begin{array}{l}\text { Appeared to assist expectoration if given } \\
\text { before postural drainage }\end{array}$ \\
\hline 18 & 48 & F. & $\begin{array}{l}\text { Winter bronchitis } 15 \text { years. Bronchiectasis } \\
\text { at right base }\end{array}$ & As No. 16 & No improvement \\
\hline 19 & 39 & M. & Bronchiectasis 16 years & $\begin{array}{l}\text { As No. 16. A stronger solution of } \\
\text { creosote- }-40 \text { per cent. }\end{array}$ & $\begin{array}{l}\text { Comp'ained of pain in the chest after } \\
\text { it halations. A brisk haemoptysis } \\
\text { followed an inhalation. }\end{array}$ \\
\hline 20 & 45 & M. & $\begin{array}{l}\text { Silicosis; bronchitis; no tubercle bacilli } \\
\text { found. Copious sputum }\end{array}$ & $\begin{array}{l}\text { Apnengene and camphengene ; } \\
\text { camphengene and creosote }\end{array}$ & No change; sputum notreduced in amount \\
\hline
\end{tabular}


tions and solutions in oil are apparently well absorbed in particles of this size in cats and dogs. If suitable conditions are found and absorption of drugs by the tracheobronchial mucous membrane is effected two great difficulties remain :

1. To give a therapeutic dose of a drug in an inhalation of moderate length.

2. To measure exactly the dose given.

\section{Local Action}

In the case of animals it has been shown that solutions in oil and water passed through a suitable atomizer, such as the Spiess-Dräger, are immediately absorbed. The droplets are deposited in a very fine spray over a great area, and it is unlikely that there will be injurious concentration on the tracheo-bronchial mucous membrane. It does not seem likely that drugs given for local action will therefore have sufficient time to produce any effect.

In view of the experiments with iodides and insulin on students doubt was felt as to whether the atomized liquid penetrated the tracheo-bronchial tree. Twenty-minute inhalations of 5 per cent. cocaine were given, the subject breathing alternatively through the nose and the mouth. It was impossible to demonstrate any diminution of sensation in the mucous membrane of the tongue, palate, fauces, post-pharyngeal wall, and nose, although these were rapidly tested as soon as the inhalation ended. The pupils, however, dilated; and there was complaint of a dry mouth and thirst.

\section{Therapeutic Application}

A small series of twenty cases of pulmonary disease were treated by inhalations. A Collinson inhaler was used. The rate of oxygen throughout was 10 litres a minute. A five-minute rest period alternated with every five minutes' inhalation. The length of a single inhalation totalled twenty minutes, and treatments were given twice a day. A record of results and a summary of the cases are given in Table II.

\section{Analysis}

Of seven cases of asthma two were completely relieved during attacks; the asthma attacks ceased. In one of these cases attacks recurred at once after discharge. One patient gained relief from earlier attacks while in hospital, but was later unaffected by inhalation. One case, given inhalation on admission, had no attacks while in hospital. Attacks occurred immediately on discharge. Three were not improved. In a twenty-minutes inhalation of apnengene, which contains adrenaline in strength 1 in 1,000 only, 0.35 to $0.4 \mathrm{c} . \mathrm{cm}$. of solution is found to be atomized. Some of this probably escapes through the respiratory valve unabsorbed.

Of nine cases of chronic bronchitis two improved. In one case the improvement has been maintained throughout the summer. The other case rapidly deteriorated again after discharge.

Of five cases of bronchiectasis postural drainage was accelerated in four-after inhalations.

In two cases of recovering congestive heart failure crepitations and diminished air entry at the bases were rapidly improved with camphengene inhalations. Subsequently camphengene was given by routine to all such cases, with improvement.

\section{Conclusions}

1. No evidence was obtained of the absorption of potassium iodide.

2. No evidence was obtained of the absorption of insulin.
3. Evidence was obtained of some influence of adrenaline on blood pressure when inhaled.

4. Inhalation of oxygen at a rate of 10 litres or more per minute led in most cases to a fall in blood pressure.

5. Evidence was obtained suggesting that inhalation of medicaments was of value in cases of chronic pulmonary congestion, but the results of treatment of a few cases of asthma and bronchitis were unsatisfactory.

REFERENCES

${ }^{1}$ Heubner, Wolfgang: Zeit. $f$. d. ges. exper. Med., 1919, x, 269.

2 Nothnagel, H.: Virchows Archiv 1877, lxxi, 414

${ }^{3}$ Fleiner, W.: Ibid., 1888, xcvii, 112

- Sehrwald, E.: Deut. Arch. f. klin. Med., 1886, xxxix, 162.

5 Kaestle: Zeit. f. phys. und diat. Therapie, 1908, xi, 276, 362

Sikorsky, I.: Centralbl. f. d. med. Wissen., 1870, viii, 817.

'Hofbauer: Zeit. f. phys. und diat. Therapie, 1908, xi, 577.

\section{THE PHYSICAL WELFARE OF YOUTH \\ BY}

LEONARD P. LOCKHART, M.D.

MEMBER NOTTINGHAMSHIRE COUNTY COUNCIL EDUCATION COMMITTEE

The questions of physical education and physical recreation are now much in the public mind. It seems desirable, therefore, that inquiries should be made into some of the factors which underlie a satisfactory conception of the issues involved. There is a tendency to forget that education and recreation are not ends in themselves, but parts of a total situation which is best comprised in the term " creative living." Nothing could be more fatal to the success of any scheme than an attempt to effect a division of the subject into watertight compartments.

An acknowledged authority on physical recreation recently suggested that a system of incentives was necessary if youths and young men were to be fired with the requisite enthusiasm for physical culture, and he proposed that the medical profession should lay down agreed standards of physique to which the male youth of the nation could aspire. On reaching the decreed stages of perfection they might then be allowed to distinguish themselves by some agreed title.

\section{The Need of Incentives}

The objections to some such arbitrary standard are not so obvious that they can be ignored, for if it is true that in the case of girls the operation of an incentive is undoubtedly responsible for a greater partiality to physical culture it might therefore be assumed that with youths something similar would be effective. The female regards beauty as an end in itself, possessed of very definite economic and biological advantages. The male on the other hand, at least in the industrial West, appears to regard the quest of bodily perfection as of considerably less importance, except in so far as athletic prowess is concerned, and he does not acknowledge that he owes it to himself, to his mate, and to the community to see that he develops his whole personality to the fullest. The incentive that operated in ancient Greece and Rome is lacking in large sections of our population to-day, and it is desirable that we should inquire how we may best create the quest of the beautiful that was once so potent along the Mediterranean coast. How can we most surely and effectively work towards realizing the ideal of a regenerated and upstanding people?

If incentives are needed, and it seems that they are, is there any other field in which to find them? Some suggest that national pride is adequate; others would invoke the objective of international contests in games and of sporting events in the air. The military aspect has been advanced, and a prominent soldier has even remarked that organized camping should be fostered with the dual aim of improving youthful health and military recruiting. However one may regard each of these suggestions they can at most affect a small minority-an elite-which would assume the role of potential gladiators 